\title{
A bat on the brink? A range-wide survey of the Critically Endangered Livingstone's fruit bat Pteropus livingstonii
}

\author{
Bronien M. Daniel, Kathleen E. Green, Hugh Doulton \\ Daniel Mohamed Salim, Ishaka Said, Michael Hudson \\ Jeff S. Dawson, Richard P. Young and Amelaid Houmadi
}

\begin{abstract}
The Livingstone's fruit bat Pteropus livingstonii is endemic to the small islands of Anjouan and Mohéli in the Comoros archipelago, Indian Ocean. The species is under threat from anthropogenic pressure on the little that remains of its forest habitat, now restricted to the islands' upper elevations and steepest slopes. We report the results of the most comprehensive survey of this species to date, and present recommendations for ongoing field conservation efforts and monitoring. Morning counts were conducted at roost sites in the wet and dry seasons during 2011-2013. Habitat structure around the roosting sites was characterized and roost numbers compared, to investigate the potential effect of habitat loss and degradation. We estimate the population to comprise c. 1,260 individuals distributed across 21 roosts on the two islands. All occupied roosting sites were restricted to a narrow altitudinal range, and roosting populations in agroforestry areas were smaller than those found in degraded and undisturbed forest. Only one of the 16 roosts on Anjouan was found in undisturbed, old-growth forest with no nearby signs of clearance for agriculture or landslides following tree-felling upslope. Following a suspected severe population decline as a result of widespread and long-term forest loss Livingstone's fruit bat has been recategorized as Critically Endangered on the IUCN Red List.
\end{abstract}

Bronwen M. Daniel, Michael Hudson* ${ }^{*}$ Jeff S. Dawson and Richard P. Young $\dagger$ (Corresponding author), Durrell Wildlife Conservation Trust, Les Augres Manor, Trinity, Jersey, Channel Islands, JE3 5BP, UK

E-mail richard.young@durrell.org

Kathleen E. Green and Hugh Doulton $\ddagger$ Bristol Zoological Society, Bristol Zoo Gardens, Clifton, Bristol, UK

Daniel Mohamed Salim, Ishaka Said and Amelaid Houmadi@ Dahari, HomboMutsamudu, Anjouan, Union des Comores

${ }^{*}$ Also at: Durrell Institute of Conservation and Ecology, University of Kent, Canterbury, Kent, UK

$\dagger$ Also at: Department of Life Sciences, Imperial College London, Silwood Park Campus, Ascot, Berkshire, UK

$\ddagger$ Also at: Dahari, Hombo-Mutsamudu, Anjouan, Union des Comores

$\S$ The original version of this article was published with an author omitted from the list of authors. A notice detailing this has been published and the error rectified in the online and print PDF and HTML copies.

Received 26 November 2015. Revision requested 24 February 2016. Accepted 9 May 2016. First published online 29 November 2016.
Keywords Comoros, Comorian flying fox, Critically Endangered, deforestation, old world fruit bat, population survey, Petropus livingstonii, western Indian Ocean

\section{Introduction}

ruit bats of the genus Pteropus are recognized as being - important pollinators and seed dispersers (Cox et al., 1991; Fujita \& Tuttle, 1991; Pierson \& Rainey, 1992), especially on isolated island systems with a low abundance of pollinator fauna (Cox et al., 1991; Carroll \& Feistner, 1996; Allen-Wardell et al., 1998; Mohd-Azlan et al., 2001), and in fragmented systems (Bollen \& Van Elsacker, 2002; Nyhagen et al., 2005). The loss of fruit bat populations, particularly of endemic species, is of conservation concern as it is thought to lead to the loss of endemic plants and a decrease in plant biodiversity (Allen-Wardell et al., 1998; Mohd-Azlan et al., 2001; Bollen et al., 2004; Nyhagen et al., 2005; Jenkins et al., 2007).

Many Pteropus species are under threat, mainly from habitat loss and hunting, both for subsistence use and for sale (Jenkins et al., 2007; Epstein et al., 2008). Of the 62 Pteropus species on the IUCN Red List (IUCN, 2016), four have already gone extinct, five are Critically Endangered, five are Endangered and 20 are Vulnerable. Many Pteropus species are limited to islands in the Pacific and Indian Oceans, where typhoons and cyclones also pose a threat to the integrity of the remaining forest fragments (Pierson \& Rainey, 1992; Carroll \& Feistner, 1996; Mickleburgh et al., 1992; Powell \& Wehnelt, 2003). As ecologically specialized island endemics with a preference for undisturbed old-growth forest (Brooke, 2001; Mildenstein et al., 2005; Nyhagen et al., 2005), many are particularly vulnerable to habitat loss. With a low reproductive rate of only one young per female per annum, Pteropus are limited in their ability to recover from population declines (Pierson \& Rainey, 1992).

At the western limit of the genus' distribution, the western Indian Ocean is home to an assemblage of eight Pteropus species (Carroll \& Feistner, 1996; Mickleburgh et al., 1992). The rarest of these is thought to be the Livingstone's fruit bat Pteropus livingstonii, which is found only on the islands of Anjouan and Mohéli in the Comoros archipelago (Anjouan, Mohéli and Grande Comore, which comprise 
the Union of Comoros, plus the French Departement of Mayotte). The species was first described by the Victorian-era explorer David Livingstone, who shot an individual on Anjouan in 1861 (Cheke \& Dahl, 1981). It is the only Pteropus species in the western Indian Ocean that is not threatened by hunting (Carroll \& Feistner, 1996; Entwistle, 2001; Jenkins et al., 2007; Mickleburgh et al., 1992), but its population is suspected to have undergone severe declines as a result of widespread deforestation since the 196os (Cheke \& Dahl, 1981; Mickleburgh et al., 1992; Reason \& Trewhella, 1994), which continues today. It was estimated that forest on the Comoro Islands was lost at a rate of 9.3\% per year during 2000-2010, the highest rate of deforestation of any country (FAO, 2010). The main causes of natural forest loss are the cutting of large trees for construction wood and the extension of the agricultural frontier, driven by unproductive agricultural systems, a high population growth rate, poverty, a lack of economic alternatives and uncertain land tenure. Only c. 35 and $25 \mathrm{~km}^{2}$ of undisturbed oldgrowth forest remains on Anjouan and Mohéli respectively, and this is largely restricted to higher elevations and steep slopes (Green, 2014a). The status of Livingstone's fruit bat was recently reassessed, and as a result of this habitat loss the species is now categorized as Critically Endangered on the IUCN Red List (Sewall et al., 2016).

A number of surveys of Livingstone's fruit bat have been conducted since the early 199 os by counting at known daytime roosts, with more intensive survey effort on Anjouan than Mohéli. In 1995 a field expedition conducted the first survey of the species by counting bats at all known long-term roosts (Trewhella et al., 1998). The population was estimated to be as few as 400 individuals, found at 12 roost sites. Following the survey a long-term community-led monitoring programme was set up, in which local people, supported by technicians from the national NGO Action Comores, conducted monthly counts at known roosts, and searches for unknown roosting sites. By 2002, 22 active roosts were known to exist across Anjouan and Mohéli and were believed to support c. 1,200 bats (Sewall et al., 2007). However, the reliability of these counts conducted by community enumerators with varying levels of training and poor access to survey equipment has not yet been assessed.

Despite its threatened status Livingstone's fruit bat receives no legal protection at national level and there are currently no long-term forest conservation measures in place on either Anjouan or Mohéli. Forest conservation initiatives are being developed, including the planned designation of the first terrestrial protected area in the Comoros (UNDP, 2013), and the development of community-conserved areas by a local NGO, Dahari. The locations and sizes of current roosts, and proximate pressures on each roost site, need to be quantified and the data made available to conservation planners to ensure these conservation initiatives take into account the needs of Livingstone's fruit bat. We report the

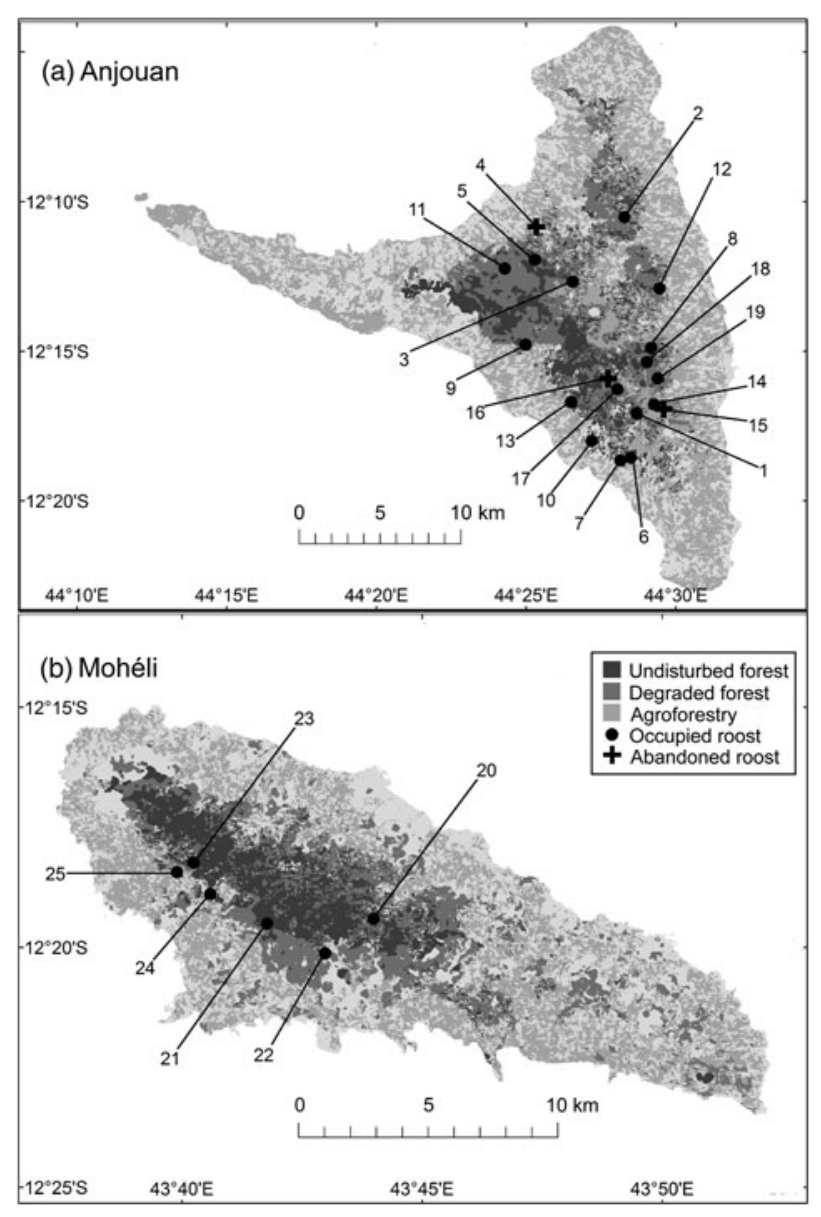

Fig. 1 Distribution of Livingstone's fruit bat Pteropus livingstonii roosts (numbers as in Table 1) on (a) Anjouan and (b) Mohéli islands in the Comoros archipelago, in the western Indian Ocean. Coverage of undisturbed and degraded forest is based on a land cover map by Green (2014a).

most comprehensive population estimate for the species, based on a 2011-2013 survey of all known roosts as well as previously unknown roosts. We characterize the condition of the forest around each roost and compare this to roost size to investigate the potential effects of habitat loss and degradation on the populations at roost sites. Based on our findings we make a series of recommendations for conservation efforts and population monitoring.

\section{Study area}

The work was conducted on the islands of Anjouan and Mohéli in the Comoros archipelago, in the Western Indian Ocean (Fig. 1). Anjouan is both the larger $\left(424 \mathrm{~km}^{2}\right)$ and higher island, reaching an elevation of $1,575 \mathrm{~m}$, and is characterized by steep ravines. Mohéli $\left(210 \mathrm{~km}^{2}\right)$ reaches only $860 \mathrm{~m}$ and consists of a single mountainous ridge. Both islands are dominated by agricultural and agroforesty areas but Mohéli retains a greater percentage of its original forest cover (Green, 2014a), partly because it has a smaller human population, of c. 35,000 . 
Anjouan has a population of c. 275,000 , and its high population density of $>640$ people $\mathrm{km}^{-2}$ has contributed to high levels of deforestation.

The annual climatic cycle in the Comoros consists of a cooler, drier season during May-October and a warm, humid season during November-April. To sample these two annual climatic extremes, and for the data to be directly comparable to previous surveys (Granek, 2002; Sewall et al., 2011), field work was carried out on Anjouan during the wet season in December 2011 and January 2012, and repeated in January 2013, and dry season counts were conducted across both Anjouan and Mohéli in June and July 2012. Limited project resources meant it was not possible to conduct a wet-season count on Mohéli.

\section{Methods}

A team of one scientist and four field technicians surveyed all known roost sites on each island in as short a time-frame as possible to minimize error caused by double counting as a result of inter-roost movements; the mean duration of the three main survey periods was 30 days. This included a total of 18 sites on Anjouan identified previously (Sewall et al., 2011) as having been used historically by Livingstone's fruit bats for roosting, and six on Mohéli (Table 1). Local reports of previously unidentified roosts were investigated by intensive searches of relevant areas of forest. Roost counts were carried out hourly during 07.00-10.00 from pre-identified vantage points, using binoculars. Vantage points were typically located c. $80-100 \mathrm{~m}$ from the roost, and slightly above or level with the crown of the trees used for roosting. Each surveyor conducted an independent count, and the results were compared after the count was finished. The final number was agreed following cross-checking of counts. The species of each tree used for roosting was recorded (during a survey of the roost site after the count was completed) along with the number of Seychelles fruit bats Pteropus seychellensis comorensis (which are readily distinguishable by their smaller size) to investigate the extent of mixing at the long-term roosts of Livingstone's fruit bats. Counts were not carried out during prolonged spells of rain or mist as this affected visibility.

Roost sites were defined as one or more trees at a discrete location (typically within $50 \mathrm{~m}$ of each other) that were used by at least one bat for roosting. To quantify the canopy structure and the composition of tree species at roost sites, the 10 nearest large trees (diameter at breast height $>45 \mathrm{~cm}$ ) to the main roosting tree (the tree containing most bats) were identified and measured. If the number of roosting trees was greater than 10, all trees that contained roosting bats were sampled. The location of each tree was recorded with a global positioning system. To measure the dimensions of the trees, the total height and height of the first branch were estimated by eye by each team member and the mean value taken. Canopy diameter was measured by two team members standing directly under opposite edges of the canopy and measuring the distance with a tape measure. Tree trunk diameter at breast height was measured using a tape measure. The Comorian names of tree species and any anthropogenic uses were identified by the Comorian field technicians and local guides.

The structure of the understorey vegetation was sampled at eight locations at 25 and $50 \mathrm{~m}$ north, south, east and west of the main roost tree. The location, list of plant species, and description of the ground substrate (rocky, loose soil or fertile soil) within a radius of $2 \mathrm{~m}$ of each sample point was also recorded. Canopy cover was measured at each point using a spherical densitometer (Lemmon, 1956). Observations of any trees felled for planks, clearance for agriculture, or damage caused by cyclones or floods were also recorded.

The land cover type (based on land cover maps produced by Green, 2014a) in which the roosts were located was identified using the geographical information system ArcGIS v. 9.3.1 (ESRI, Redlands, USA). The land cover types were undisturbed forest (old-growth forest with closed canopy and little trace of human impact); degraded forest (mainly closed canopy consisting of native species but with abundant signs of human pressure, such as selective logging and/or clearing of understorey vegetation; some presence of non-native trees or crops); agroforestry (agroforestry species with natural or non-natural understorey); and plantation (few native and/ or non-native trees present but dominated by crops). Percentage canopy cover at the roost site, diameter at breast height of the roost trees, elevation and land cover type were included as candidate variables in the analysis. All statistical analyses were conducted in $R v$. 2.11.1 (R Development Core Team, 2010). An initial Poisson generalized linear model was run to investigate the relationship between the environmental variables and mean wet-season roost size in the 2 survey years. Wet-season roost counts were considered to be a superior estimate of population size to dry-season counts, as fruit bats are less dispersed throughout the landscape in the wetter part of the year (Mickleburgh et al., 1992; Jenkins et al., 2007). Goodness-of-fit tests revealed an overdispersion parameter of 9.79 for the Poisson generalized linear model, and therefore the standard errors were corrected using a quasi-Poisson generalized linear model in which the variance was the dispersion parameter multiplied by the mean of the dependent variable. Model selection was carried out using stepwise backward deletion of the least significant variable until all variables retained were significant at $\alpha=0.05$.

The Extent of Occurrence (EoO) and Area of Occupancy (AoO) of the species were calculated to provide two metrics of its geographical range, to guide reassessment for the IUCN Red List. The former was estimated by drawing a minimum convex polygon (MCP) around the outermost known active roosts on both islands. AoO was calculated 
TABLE 1 Survey results from roost sites of Livingstone's fruit bats Pteropus livingstonii on the islands of Anjouan and Mohéli in the Comoros archipelago (Fig. 1), with the land cover type, altitude, presence of the Seychelles fruit bat Pteropus seychellensis comorensis, and land uses and impacts within a $100 \mathrm{~m}$ radius.

\begin{tabular}{|c|c|c|c|c|c|c|c|}
\hline \multirow[b]{2}{*}{ Roost name } & \multicolumn{3}{|c|}{ Roost count (Number of trees used for roosting) } & \multirow[b]{2}{*}{$\begin{array}{l}\text { Land cover } \\
\text { type }\end{array}$} & \multirow[b]{2}{*}{$\begin{array}{l}\text { Altitude } \\
(\mathrm{m})\end{array}$} & \multirow[b]{2}{*}{$\begin{array}{l}\text { Seychelles } \\
\text { fruit bat }^{*}\end{array}$} & \multirow[b]{2}{*}{ Land uses \& impacts within $100 \mathrm{~m}$} \\
\hline & $\begin{array}{l}\text { Wet season } \\
2011-2012\end{array}$ & $\begin{array}{l}\text { Dry season } \\
2011-2012\end{array}$ & $\begin{array}{l}\text { Wet season } \\
2012-2013\end{array}$ & & & & \\
\hline \multicolumn{8}{|l|}{ Anjouan } \\
\hline 1. Adda (Chava) & $28(2)$ & $18(2)$ & $41(3)$ & $\begin{array}{l}\text { Degraded } \\
\text { forest }\end{array}$ & 999 & & Extensive agriculture \& felling for construction \\
\hline $\begin{array}{l}\text { 2. Bazimini } \\
\text { (Hamogne-Panga) }\end{array}$ & $75(7)$ & $37(5)$ & $56(6)$ & $\begin{array}{l}\text { Degraded } \\
\text { forest }\end{array}$ & 771 & $>10$ & Encroachment of agriculture \\
\hline 3. Dindri (Dremelani) & $6(2)$ & $0(0)$ & $6(2)$ & Agroforestry & 762 & $>200$ & $\begin{array}{l}\text { Extensive felling for firewood, construction \& agricul- } \\
\text { ture since 2000; trees sparse; loose soil }\end{array}$ \\
\hline $\begin{array}{l}\text { 4. Hombo (Mratsini/ } \\
\text { Massakini) }\end{array}$ & $87(3)$ & $164(3)$ & $146(3)$ & $\begin{array}{l}\text { Undisturbed } \\
\text { forest }\end{array}$ & 812 & & Undisturbed forest; steep \\
\hline 5. Hombo (Mkirini) & 0 & 0 & & Agriculture & 369 & & Roost abandoned; agricultural fields \\
\hline 6. Kangani (Kove) & $29(2)$ & $12(2)$ & $25(2)$ & $\begin{array}{l}\text { Degraded } \\
\text { forest }\end{array}$ & 616 & & Extensive agriculture \& felling for construction \\
\hline 7. Kangani (Bwejou) & $3(2)$ & $5(3)$ & $3(2)$ & Agroforestry & 645 & & $\begin{array}{l}\text { Extensive agriculture, bare soil \& few remaining large } \\
\text { trees }\end{array}$ \\
\hline 8. Limbi (Trondroni) & $69(5)$ & $46(3)$ & $53(4)$ & $\begin{array}{l}\text { Undisturbed } \\
\text { forest }\end{array}$ & 977 & & Mostly undisturbed forest; some banana planting \\
\hline 9. Lingoni (Yimere) & Present & Present & & $\begin{array}{l}\text { Undisturbed } \\
\text { forest }\end{array}$ & 741 & & Undisturbed forest; steep; major landslide in 2007 \\
\hline 10. Moya (Makini) & $77(7)$ & $73(14)$ & $75(5)$ & $\begin{array}{l}\text { Degraded } \\
\text { forest }\end{array}$ & 626 & & $\begin{array}{l}\text { Encroachment of agriculture; landslides observed in } \\
\text { May } 2012\end{array}$ \\
\hline 11. Mpage (Massakini) & $53(6)$ & $37(5)$ & $128(10)$ & $\begin{array}{l}\text { Degraded } \\
\text { forest }\end{array}$ & 750 & & Clearance for agriculture started in May 2012 \\
\hline 12. Mromaji (Bandra) & $34(3)$ & $31(3)$ & $32(4)$ & Agroforestry & 452 & $>200$ & Extensive agriculture \\
\hline $\begin{array}{l}\text { 13. Outsa } \\
\text { (Dindri-Jumpbe) }\end{array}$ & $19(2)$ & $22(2)$ & $33(2)$ & Agroforestry & 615 & $>90$ & $\begin{array}{l}\text { Extensive agriculture; in } 2011 \text { a road was constructed } \\
\text { within } 200 \mathrm{~m} \text { of roost }\end{array}$ \\
\hline 14. Outsa (Hadzoum) & 0 & 0 & & Agriculture & 698 & & Roost abandoned; agricultural field \\
\hline 15. Nindri-Kowet & $67(9)$ & $18(3)$ & $81(3)$ & $\begin{array}{l}\text { Degraded } \\
\text { forest }\end{array}$ & 610 & & $\begin{array}{l}\text { Extensive agriculture; roost trees felled in high winds in } \\
\text { May } 2012\end{array}$ \\
\hline 16. Ouzini (Moihajou) & $105(13)$ & $72(14)$ & $88(13)$ & $\begin{array}{l}\text { Degraded } \\
\text { forest }\end{array}$ & 953 & & Landslide in May 2012 \\
\hline 17. Ouzini (Havoundre) & 0 & 0 & & Agriculture & 803 & & Roost abandoned; agricultural field \\
\hline $\begin{array}{l}\text { 18. Salamani } \\
\text { (Mroni-Papane) }\end{array}$ & $97(5)$ & $40(14)$ & $59(5)$ & $\begin{array}{l}\text { Degraded } \\
\text { forest }\end{array}$ & 797 & 1 & $\begin{array}{l}\text { Extensive clearance for agriculture \& felling for con- } \\
\text { struction wood since } 1995\end{array}$ \\
\hline $\begin{array}{l}\text { 19. Salamani } \\
\text { (Maveyajou) }\end{array}$ & & $9(2)$ & $15(2)$ & $\begin{array}{l}\text { Degraded } \\
\text { forest }\end{array}$ & 1,078 & & $\begin{array}{l}\text { First located in 2009; some clearance for agriculture \& } \\
\text { felling for construction wood }\end{array}$ \\
\hline Total & 749 & 584 & 841 & & & & \\
\hline
\end{tabular}




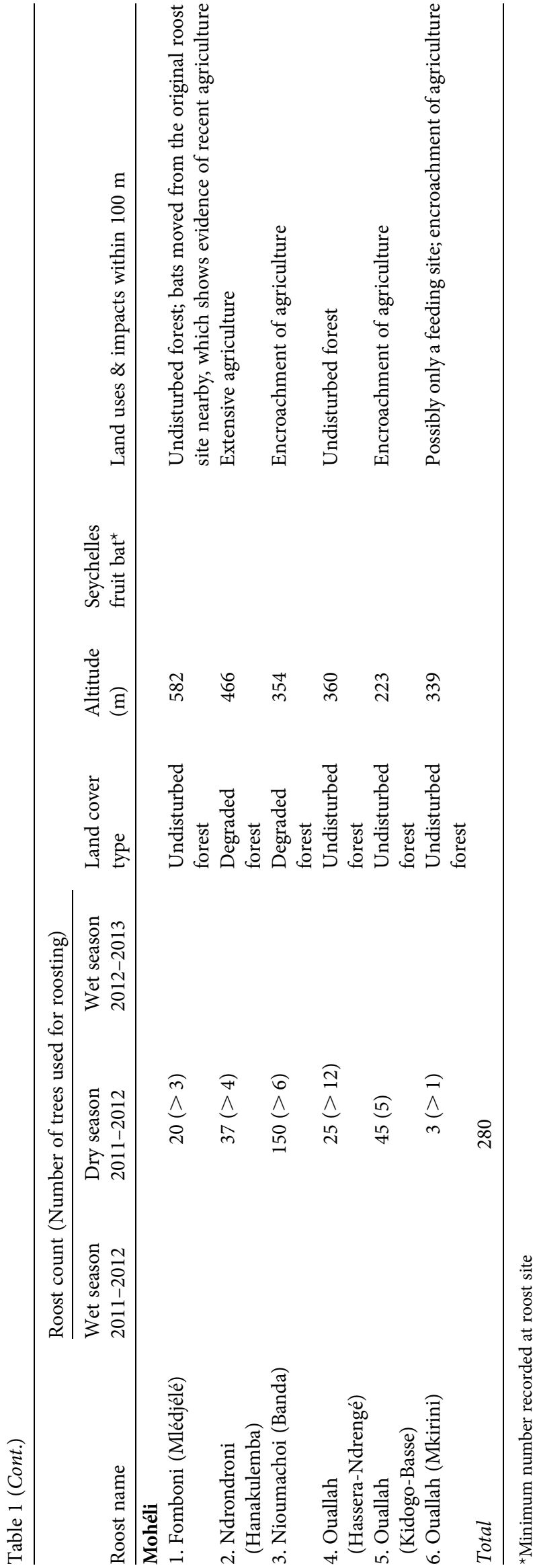

as the surface area of undisturbed and degraded forest and agroforestry within the MCP located between the altitudes of the lowest and highest currently active roosts $(452-1,078 \mathrm{~m}$ on Anjouan; 223-582 m on Mohéli).

\section{Results}

On Anjouan 15 of the 18 historical roost sites identified in the surveys of 1998-2003 (Sewall et al., 2011) were found to be still active. Ouzini-Havoundre appeared to be abandoned following extensive recent tree-felling (Fig. 1) and no individuals were found at Hombo and Outsa-Hadzoum; the sites are now agricultural fields. No bats were found at the Dindri roost during the dry season but six individuals were counted during both wet-season surveys. The Lingoni roost, previously reported as being one of the largest (Sewall et al., 2011), was visited but accurate counts were not possible as no clear vantage point could be accessed safely. Following reports by local farmers, a small, previously unknown roost site was located at Salamani Maveyajou. We therefore consider that there are currently 16 active roosts on Anjouan.

In the wet season of 2012, 749 individuals were recorded at Anjouan roosts (not including the Lingoni roost; Table 1). During the following dry season 584 individuals were recorded, including nine at the newly discovered roost in Salamani. In the wet season of 2013,841 individuals were recorded across the Anjouan roosts (not including the Lingoni roost), including 15 at the newly discovered roost, confirming that the newly identified site is used in both seasons (Table 1). The altitudinal range of occupied roosts on Anjouan was 452-1,078 $\mathrm{m}$ (Table 1), and the four abandoned roosts were all located at $369-803 \mathrm{~m}$.

All five roost sites on Mohéli identified during 1998-2003 were found to be occupied in 2012 (Fig. 1); however, the roost at Fomboni was a few hundred metres from the historically recorded location. Following local reports, three individuals were found at a sixth site in Ouallah (Mkirini), but further monitoring is required to confirm that this is a roost rather than a feeding site. A seventh roost was reported locally but confirmation of its existence was not possible. All Mohéli roosts were found at altitudes of $223-582 \mathrm{~m}$. A total of 280 individuals were recorded in the dry season; no wet-season counts were conducted. Summing the Anjouan 2013 wetseason counts and the Mohéli dry season counts (Table 1) we calculate the minimum global Livingstone's fruit bat population to be 1,121 individuals. The mean size of roosting populations in the dry season was $46.7 \pm$ SE 9.1 on Mohéli and $30.7 \pm$ SE 21.5 on Anjouan (Table 1).

We estimated the EoO of Livingstone's fruit bat to be $866.7 \mathrm{~km}^{2}$ (an MCP around all occupied roosts). Within the EoO the surface area of potentially occupied habitat, and therefore the AoO, was estimated to be $113.6 \mathrm{~km}^{2}$ in total $\left(80.6 \mathrm{~km}^{2}\right.$ on Anjouan, $33.0 \mathrm{~km}^{2}$ on Mohéli). 


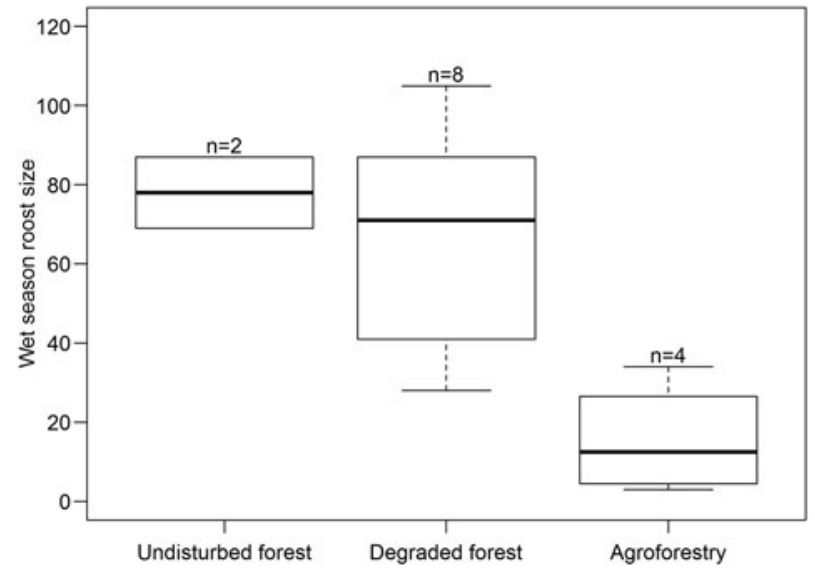

Fig. 2 Boxplot of Livingstone's fruit bat's wet-season roost size in undisturbed forest, degraded forest and agroforestry areas. Mean roost size is significantly lower in agroforestry areas than in undisturbed $(\mathrm{P}=0.005)$ and degraded forest $(\mathrm{P}=0.008)$, with no significant difference between the latter two $(\mathrm{P}=0.364)$.

In the analysis of environmental correlates of roost size, only land cover type was retained in the final model $\left(\mathrm{F}_{(2,13)}=8.30, \mathrm{P}=0.006\right)$, with evidence of a significantly lower wet-season roost size in agroforestry areas (mean $=17.0$ $\pm \mathrm{SE} 7.4, \mathrm{n}=4$ ) than in undisturbed (mean $=88.8 \pm \mathrm{SE} 27.8$, $\mathrm{n}=2 ; \mathrm{P}=0.005)$ and degraded forest (mean $=72.5 \pm$ SE 8.5, $\mathrm{n}=7 ; \mathrm{P}=0.008 ;$ Fig. 2). Although the mean roost size in undisturbed forest was greater than in degraded forest, there was no evidence of a significant difference $(\mathrm{P}=0.364)$.

All but one occupied roost site on Anjouan, HomboMrantsini, had signs of vegetation clearance or significant erosion (Table 1). Severe weather caused landslides or brought down roost trees at three roost sites during the survey period alone and signs of recent felling of trees for agriculture and/or construction wood were evident at 13 of the 16 occupied sites (Plate 1 ).

Only four tree species were used for roosting on Mohéli, compared with 12 on Anjouan (Table 2). Ficus exasperata was the only species used as a roost tree on both islands; it was the most frequently used species for roosting and was found at the greatest number of sites. Larger numbers of $F$. exasperata roost trees were found mainly at elevations $<500 \mathrm{~m}$. Of all tree species used for roosting, $80 \%$ were native or endemic to the Comoros, with the hard wood Gyrostipula comoriensis being the most frequently used for roosting on Anjouan ( $\mathrm{n}=15$ trees). Albizia glaberrima was the only introduced species used for roosting on Anjouan. Two introduced species were used on Mohéli: Albizia lebbeck was the most frequently used $(\mathrm{n}=9)$ at three sites, and Terminalia catappa was used only at one site (Table 2).

\section{Discussion}

We report the most comprehensive survey to date of Livingstone's fruit bat, in which we recorded 749-841 individuals at 15 long-term roosts and one previously unknown roost on Anjouan, and 280 individuals at five roosts on Mohéli during the dry season. The largest roosts on Anjouan were found at sites within a narrow altitudinal range of 600-960 $\mathrm{m}$, with three roosts located at lower altitudes found to be abandoned. Given the extent and intensity of the survey, alongside a contemporaneous major biodiversity assessment of Anjouan's forest (Green, 2014b), we consider it unlikely that we missed any Livingstone's fruit bat roosts supporting more than a few individuals on this island.

However, resource and logistical constraints meant the survey had a number of limitations. It was not possible to conduct simultaneous counts at all the roosts on each island, and therefore we cannot rule out the possibility that bats were moving between roosts within the survey period and were double-counted or missed entirely, although these sources of bias are likely to balance each other out. On Anjouan a landslide rendered the Lingoni roost inaccessible and no counts were possible. Bat numbers at this roost were previously reported to have been high (Sewall et al., 2007), with 96 counted in 1998 (Granek, 2002) and 125 in 2002 (Sewall et al., 2011). Assuming the Lingoni roost population has not changed markedly since then we are likely to have underestimated the Anjouan population by c. 100 individuals.

Counts on Mohéli were only possible during the dry season, when roost populations on Anjouan were on average $30 \%$ lower than in the wet season. This is in line with previous observations of this species (Granek, 2002) and seasonal changes in colony size of other Pteropus species (Mickleburgh et al., 1992; Jenkins et al., 2007), and is attributed to the lower availability of fruit during the dry season resulting in bats roosting more frequently at temporary sites nearer to food resources. If we adjust the Anjouan population estimate to take into account the missing Lingoni count and increase the Mohéli count by $30 \%$ to allow for seasonal differences, we estimate the global population of Livingstone's fruit bat to be c. 1,260 individuals.

This is substantially lower than numbers of any other Indian Ocean fruit bat for which robust population data exist, and possibly the lowest of any fruit bat globally. The Critically Endangered Rodrigues fruit bat Pteropus rodricensis has the next lowest known population size of c. 10,000 individuals (V. Tatayah, pers. comm.). The Vulnerable Aldabra fruit bat Pteropus aldabrensis is thought to be low in number but has not been subject to rigorous surveys and therefore its population size is uncertain. It is difficult to relate the current population estimate to those published previously (Reason \& Trewhella, 1994; Trewhella et al., 1998; Granek, 2002; Sewall et al., 2007), to quantify population trends in this species. In particular, the survey intensity and number of roost sites visited has varied between studies. Prior to this study the most recent published estimate of 1,200 individuals (Sewall et al., 2007), based on surveys conducted in 2002, was obtained using a team of local 


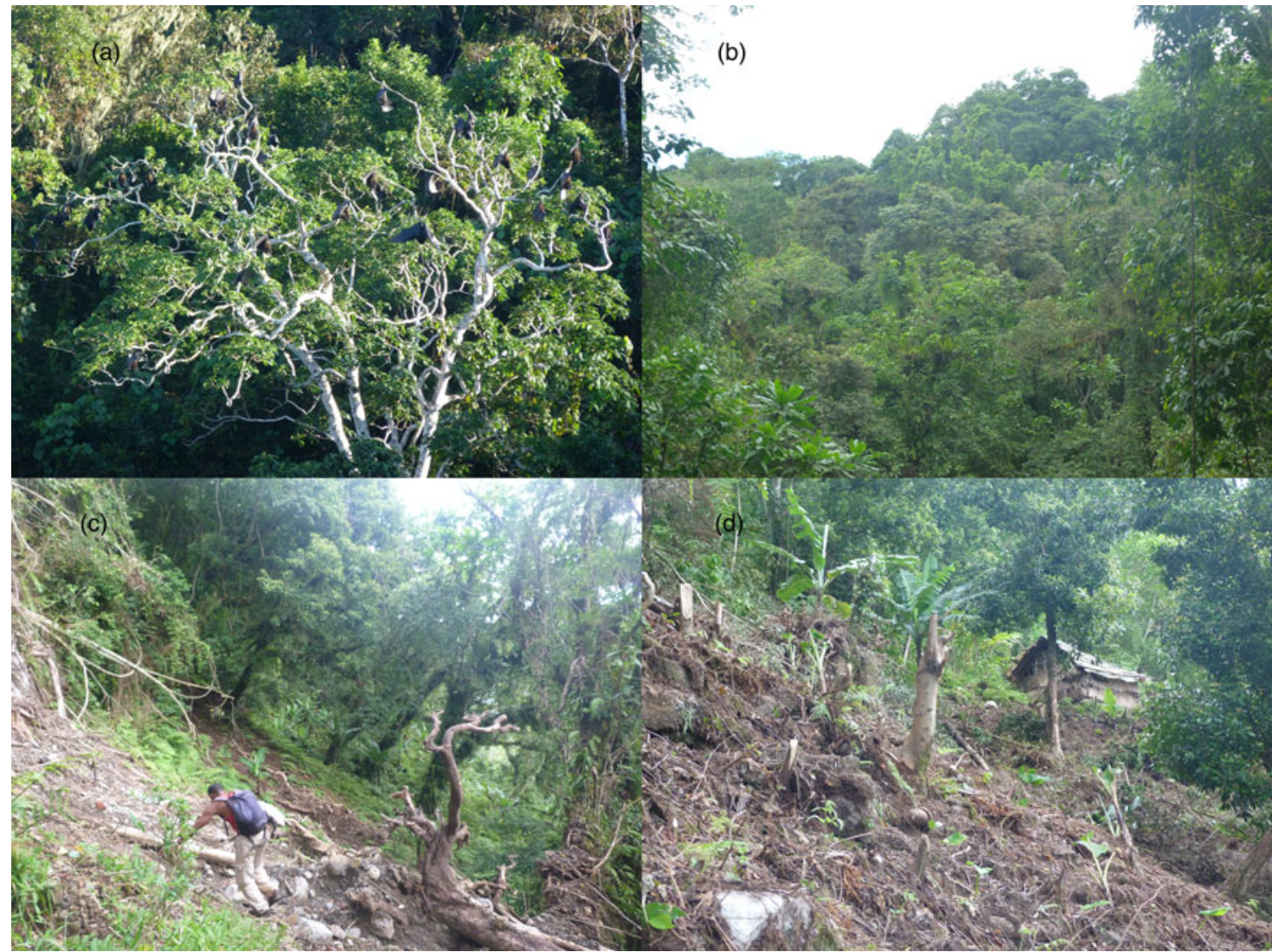

Plate 1 Livingstone's fruit bat Pteropus livingstonii roost sites on the islands of Anjouan and Mohéli in the Comoros archipelago (Fig. 1). (a) View of the Moya roost from the survey point; (b) undisturbed forest at the Fomboni roost; (c) landslide at the Ouzini-Moihajou roost; (d) unstable soil resulting from recent land clearance for agriculture at the Mpage roost.

community members with variable levels of training and access to survey equipment, and the reliability of these counts has never been assessed. The current study used a small number of well-trained and experienced observers, who conducted simultaneous counts at sites, and therefore the estimate reported here is likely to be the most reliable to date.

However, given the ongoing habitat loss and degradation over the previous decade, our estimate of 1,26o bats probably does not indicate that the population has remained unchanged across this time period. Deforestation rates in the Comoros were the highest of any country during 20002010 (FAO, 2010). Three roosts on Anjouan have been lost since the early 2000 , following tree felling and clearance for agriculture. We found evidence of agricultural encroachment, under-planting of crops, tree-cutting or major landslides following clearance of vegetation within $50 \mathrm{~m}$ of all but one of the 16 occupied roosts on Anjouan. During the study heavy rains resulted in flooding and landslides, which swept away at least two trees used for roosting and opened the canopy at three roost sites. Only the Hombo-Mratsini roost appears to be under no immediate threat from vegetation clearance or landslides as it is situated on a well-forested slope that is too steep for agriculture. Fragmented forests are more vulnerable to damage caused by severe weather, as edge effects such as increased air temperature, reduced canopy cover and elevated tree mortality increase with proximity to the forest boundaries (Laurance et al., 2002). On Anjouan the remaining natural forest is fragmented and found only on steep slopes at high elevations, and therefore we expect further damage to roosting sites in the coming years. Furthermore, all 15 tree species used for roosting are currently exploited by local people for firewood, animal forage, medicinal uses and producing planks. Eleven of these are hard woods, of which eight are known to be felled for planks used in building construction, and the emerging use of chain-saws and a commercial market on Anjouan appear to be driving widespread tree cutting (H. Doulton, pers. comm.).

The only environmental variable associated with size of roost populations was land cover, with roosts located in agroforestry areas being on average 3-5 times smaller than in degraded and undisturbed forests. A previous study (Granek, 2002) found that the size of bat roosts was positively associated with increasing canopy cover, presence of a watercourse, steepness of slopes and a south-east aspect, suggesting they prefer to roost at sites with higher humidity and sheltered from the midday sun and stronger winds. The newly discovered Anjouan roost was found at an altitude of 
TABLE 2 Tree species used for roosting by Livingstone's fruit bats on the islands of Anjouan and Mohéli in the Comoros archipelago (Fig. 1), with no. of roost trees, no. of roost sites, geographical status, human uses, and whether the species is known to be used by the bats for feeding.

\begin{tabular}{|c|c|c|c|c|c|c|}
\hline Tree species & $\begin{array}{l}\text { No. of roost } \\
\text { trees }\end{array}$ & $\begin{array}{l}\text { No. of roost } \\
\text { sites }\end{array}$ & Island & $\begin{array}{l}\text { Geographical } \\
\text { status }\end{array}$ & Human uses & $\begin{array}{l}\text { Used for } \\
\text { feeding }\end{array}$ \\
\hline Ficus exasperata & 23 & 12 & $\begin{array}{l}\text { Anjouan \& } \\
\text { Mohéli }\end{array}$ & Native & Animal forage, firewood & Yes \\
\hline $\begin{array}{l}\text { Gyrostipula } \\
\text { comoriensis }\end{array}$ & 15 & 6 & Anjouan & Native & Planks, firewood & \\
\hline Gambeya spp. & 10 & 6 & Anjouan & Native & Planks (high demand) & \\
\hline Ficus lutea & 10 & 6 & Anjouan & Native & Animal forage, firewood & Yes \\
\hline Nuxia pseudodentata & 10 & 8 & Anjouan & Endemic & Planks, firewood & \\
\hline Albizia lebbeck & 9 & 3 & Mohéli & Introduced & Animal forage, firewood & \\
\hline Ocotea comoriensis & 6 & 3 & Anjouan & Endemic & $\begin{array}{l}\text { Planks (high demand), } \\
\text { firewood }\end{array}$ & Yes \\
\hline $\begin{array}{c}\text { Weinmannia } \\
\text { comoriensis }\end{array}$ & 5 & 4 & Anjouan & Endemic & $\begin{array}{l}\text { Planks (high demand), } \\
\text { firewood }\end{array}$ & Yes \\
\hline $\begin{array}{l}\text { Brachylaena } \\
\text { ramiflora }\end{array}$ & 5 & 5 & Anjouan & Native & Firewood & \\
\hline Ficus pirifolia & 3 & 3 & Anjouan & Native & Animal forage, medicinal & Yes \\
\hline Terminalia catappa & 3 & 1 & Mohéli & Introduced & Animal forage, firewood & Yes \\
\hline $\begin{array}{l}\text { Antidesma } \\
\text { hildebrandtii }\end{array}$ & 2 & 1 & Anjouan & Native & Planks & \\
\hline Albizia glaberrima & 2 & 2 & Anjouan & Introduced & Animal forage, firewood & \\
\hline Khaya comorensis & 2 & 2 & Mohéli & Endemic & Planks, medicinal & Yes \\
\hline Cryptocarya spp. & 1 & 1 & Anjouan & Native & Planks & \\
\hline
\end{tabular}

$1,078 \mathrm{~m}$ but all others are located below 1,000 $\mathrm{m}$ despite the majority of remaining undisturbed forest lying above this elevation; this suggests there is an altitudinal limit to roosting, although the mechanism for this is not clear.

Given the suspected severe population decline as a result of widespread and long-term forest loss, with these threats continuing even around long-term roosting sites, Livingstone's fruit bat has now been recategorized as Critically Endangered on the IUCN Red List (Sewall et al., 2016). The species is in urgent need of conservation measures. In the western Indian Ocean and beyond there have been some notable conservation successes in the recovery of fruit bats; for example, the Pemba fruit bat Pteropus voeltzkowi population in Tanzania was reduced to only a few hundred individuals by the early 1990s, following severe habitat fragmentation and hunting for food (Mickleburgh et al., 1992). Since the establishment of a community-based conservation programme enforcing habitat protection and a reduction in hunting in the mid 1990 s (Entwistle, 2001), the population had increased to c. 19,000 by the end of 2006 (Juma, 2007). The Rodrigues fruit bat has recovered from just a few hundred individuals in the 1970s to perhaps $>10,000$ today thanks to long-term forest restoration work and a moratorium on hunting (Powell \& Wehnelt, 2003). Recovery of Livingstone's fruit bat in a similar way will be challenging considering that hunting bans have played an important role in these successful recoveries of other Pteropus species (Mickleburgh et al., 1992; Robinson et al., 2010) and that hunting is not a threat in the Comoros.
Efforts are now underway by the NGO Dahari to conserve the southern Moya forests of Anjouan to protect and restore water catchments and biodiversity. The project intervention zone covers seven roosts of 250-400 bats. Alongside this initiative are government-led plans to establish the first terrestrial protected area on Anjouan, around the Ntringui forest block, and to extend the reach of the Mohéli Marine Park to forest habitat (UNDP, 2013). However, given the vulnerability of the remaining roost sites to erosion, the apparent fidelity of the bat to these long-term roosts, and the lack of remaining suitable habitat for roosts, local-scale action to protect these sites is urgent. This is in line with previous recommendations by Sewall et al. (2011) for local-scale forest reserves. The challenge, however, will be to design a locally acceptable and sustainable mechanism that will both protect and restore roost sites as well as offset the opportunity costs to local impoverished farmers.

A payment for ecosystem services scheme to protect bat roosts may form part of the solution and is being trialled by local NGO Dahari. They are currently signing agreements with landholders around three pilot roost sites, with the aim of protecting the roost trees from felling and gradually reforesting the surrounding area with native trees to provide food and shade. In return the landholders will be supported by Dahari to improve agricultural revenues from their other plots through provision of improved varieties of banana and taro to plant under the native forest cover. In the longer term the aim is for the initiative to be financed through 
ecotourism and contributions from partner zoos holding the species for in situ conservation.

However, identifying specific conservation recommendations beyond protection of important roost sites is hampered by a lack of knowledge of the distribution of other key ecological resources, such as the main foraging sites. Future study of the population dynamics of Livingstone's fruit bats is necessary to understand the degree of movement between roosts and islands. Most importantly the feeding ecology of the species needs to be investigated further than initial studies (Trewhella et al., 2001; Sewall, 2002) to understand the availability of food resources and to identify important feeding sites requiring protection. This work would also help to elucidate the bat's role in the ecosystem as a pollinator and seed disperser, and therefore its potentially high-value role in forest dynamics.

\section{Acknowledgements}

We are grateful to the following funders who supported the field surveys: the UK Government's Darwin Initiative, l'Agence Française de Développement, The Global Environment Facility, and the United Nations Development Programme through the Programme of Work on Protected Areas. We also thank our partner institutions that supported this work, notably the Comorian government, the University of the Comoros, and the Centre National de Documentation et de Recherche Scientifique.

\section{Author contributions}

$\mathrm{BD}$ led the data collection, data analysis and drafting of the article. KG conducted data collection and analysis and made comments on the article. HD helped draft and edit the article. DS and IS advised on survey design and collected field data. MH and JD supported data analysis and provided comments on the article. RY oversaw the design and delivery of the study and drafted and edited the article.

\section{References}

Allen-Wardell, G., Bernhardt, P., Bitner, R., Burquez, A., Buchmann, S., CAne, J. et al. (1998) The potential consequences of pollinator declines on the conservation of biodiversity and stability of food crop yields. Conservation Biology, 12, 8-17.

Bollen, A. \& Van Elsacker, L. (2002) Feeding ecology of Pteropus rufus (Pteropodidae) in the littoral forest of Sainte Luce, SE Madagascar. Acta Chiropterologica, 4, 33-47.

Bollen, A., Van Elsacker, L. \& Ganzhorn, J.U. (2004) Relations between fruits and disperser assemblages in a Malagasy littoral forest: a community-level approach. Journal of Tropical Ecology, 20, 599-612.

Brooke, A.P. (2001) Population status and behaviours of the Samoan flying fox (Pteropus samoensis) on Tutuila Island, American Samoa Journal of Zoology, 254, 309-319.
Carroll, J.B. \& Feistner, A.T.C. (1996) Conservation of western Indian Ocean fruit bats. In Biogéographie de Madagascar (ed. W. R. Louren), pp. 329-335. Institut Français de Recherche Scientifique pour le Developpement en Cooper, Paris, France.

Cheкe, A.S. \& DAHL, J.F. (1981) The status of bats on western Indian Ocean islands, with special reference to Pteropus. Mammalia, 45, 205-238.

Conder, P. (2008) Percy Island flying fox. In The Mammals of Australia, 3rd edition (eds S. Van Dyck \& R. Strahan), pp. 433-434. Reed New Holland, Sydney, Australia.

Cox, P.A., Elmqvist, T., Pierson, E.D. \& Rainey, W.E. (1991) Flying foxes as strong interactors in south Pacific island ecosystems: a conservation hypothesis. Conservation Biology, 5, 448-454.

Entwistle, A. (2001) Community-based protection successful for the Pemba flying fox. Oryx, 35, 355-356.

Epstein, J.H., Prakash, V., Smith, C.S., Daszak, P., McLaughlin, A.B., Meenan, G. et al. (2008) Henipavirus infection in fruit bats (Pteropus giganteus), India. Emerging Infectious Diseases, 14, 1309-1311.

FAO (2010) Évaluation des Ressources Forestieres Modiales 2010. Rapport National: Comores. Report \#FRA2010/044. Food and Agriculture Organization of the United Nations, Rome, Italy.

Fujita, M.S. \& Tuttle, M.D. (1991) Flying foxes (Chiroptera: Pteropodidae): threatened animals of key ecological and economic importance. Conservation Biology, 5, 455-463.

Granek, E. (2002) Conservation of Pteropus livingstonii based on roost site habitat characteristics on Anjouan and Moheli, Comoros Islands. Biological Conservation, 108, 93-100.

GreEn, K. (2014a) Land Cover Mapping of the Comoros Islands: Methods and Results. Engagement Communautaire pour le Développement Durable, Bristol Conservation and Science Foundation, Durrell Wildlife Conservation Trust.

Green, K. (2014b) Terrestrial Biodiversity Mapping of the Comoro Islands: Methods and Results. Engagement Communautaire pour le Développement Durable, Bristol Conservation and Science Foundation, Durrell Wildlife Conservation Trust.

IUCN (2016) The IUCN Red List of Threatened Species 2016. Http:// www.iucnredlist.org [accessed 10 November 2016].

Jenkins, R.K.B., Racey, P.A., Andriafidison, D., Razafindrakoto, N., Razafimahatratra, E., Rabearivelo, A. et al. (2007) Not rare, but threatened: the endemic Madagascar flying fox Pteropus rufus in a fragmented landscape. Oryx, 41, 263-271.

Jum A, J. (2007) Conservation of Indigenous Forest and Endemic Species on Pemba Island. Unpublished report by Fauna \& Flora International, Nairobi, Kenya.

Laurance, W.F., Lovejoy, T.E., Vasconcelos, H.L., Bruna, E.M., Didham, R.K., Stouffer, P.C. et al. (2002) Ecosystem decay of Amazonian forest fragments: a 22-year investigation. Conservation Biology, 16, 605-618.

LEMmon, P.E. (1956) A spherical densiometer for estimating forest overstory density. Forest Science, 2, 314-320.

Mickleburgh, S.P., Hutson, A.M. \& Racey, P.A. (1992) Old World Fruit Bats: An Action Plan for their Conservation. IUCN, Gland, Switzerland.

Mildenstein, T.L., Stier, S.C., Nuevo-Diego, C.E. \& Mills, L.S. (2005) Habitat selection of endangered and endemic large flying-foxes in Subic Bay, Philippines. Biological Conservation, 126, 93-102.

Mohd-Azlan, J., Zubaid, A. \& Kunz, T.H. (2001) Distribution, relative abundance, and conservation status of the large flying fox, Pteropus vampyrus, in Peninsular Malaysia: a preliminary assessment. Acta Chiropterologica, 3, 149-162.

Nyhagen, D.F., Turnbull, S.D., Olesen, J.M. \& Jones, C.G. (2005) An investigation into the role of the Mauritian flying fox, Pteropus niger, in forest regeneration. Biological Conservation, 122, 491-497. 
Pierson, E.D. \& Rainey, W.E. (1992) The biology of flying foxes of the genus Pteropus: a review. In Pacific Island Flying Foxes: Proceedings of an International Conservation Conference (eds D.E. Wilson \& G.L. Graham), pp. 1-17. United States Fish and Wildlife Service, Washington, DC, USA.

Powell, V.J. \& Wehnelt, S.C. (2003) A new estimate of the population size of the Critically Endangered Rodrigues fruit bat Pteropus rodricensis. Oryx, 37, 353-357.

R Development Core Team (2010) R: A Language and Environment for Statistical Computing. The R Foundation for Statistical Computing, Vienna, Austria.

Reason, P.F. \& Trewhella, W.J. (1994) The status of Pteropus livingstonii in the Comores. Oryx, 28, 107-114.

Robinson, J.E., Bell, D.J., Saleh, F.M., Suleiman, A.A. \& Barr, I. (2010) Recovery of the Vulnerable Pemba flying fox Pteropus voeltzkowi: population and conservation status. Oryx, 44, 416-423.

Sewall, B.J. (2002) Fruit bat ecology and conservation in the Comoros Islands. MSc thesis. University of Minnesota, Minneapolis, USA.

Sewall, B.J., Granek, E.F., Moutui, M.F.E., Trewhella, W.J., Reason, P.F., Rodríguez-Clark, K.M. et al. (2007) Conservation Action Plan for Livingstone's Flying Fox: A Strategy for an Endangered Species, a Diverse Forest, and the Comorian People. Union of the Comoros.

Sewall, B.J., Freestone, A.L., Moutui, M.F., Tollibou, N., Saìd, I., Toumani, S.M. et al. (2011) Reorienting systematic conservation assessment for effective conservation planning. Conservation Biology, 25, 688-696.

Sewall, B.J., Young, R., Trewhella, W.J., Rodríguez-Clark, K.M. \& Granek, E.F. (2016) Pteropus livingstonii. The IUCN Red List of Threatened Species 2016: e.T18732A22081502. Http://dx.doi. org/10.2305/IUCN.UK.2016-2.RLTS.T18732A22081502.en [accessed 1 October 2016].

Trewhella, W.J., Reason, P.F., Clark, K.M. \& Garrett, S.R.T. (1998) The current status of Livingstone's flying fox (Pteropus livingstonii) in the Federal Islamic Republic (RFI) on the Comores. Phelsuma, 6, 32-40.

Trewhella, W.J., Rodríguez-Clark, K.M., Davies, J.G., Reason, P.F. \& Wray, S. (2001) Sympatric fruit bat species (Chiroptera: Pteropodidae) in the Comoro Islands (Western Indian Ocean): diurnality, feeding interactions and their conservation implications. Acta Chiropterologica, 3, 135-147.

Trewhella, W.J., Rodríguez-Clark, K.M., Corp, N., Entwistle, A., Garrett, S.R.T., Granek, E. et al. (2005) Environmental education as a component of multidisciplinary conservation programs: lessons from conservation initiatives for Critically Endangered fruit bats in the Western Indian Ocean. Conservation Biology, 19, 75-85.

UNDP (2013) Human Development Report 2013. The Rise of the South: Human Progress in a Diverse World. United Nations Development Programme, New York, USA.

\section{Biographical sketches}

Bronten Daniel and Kathleen Green were involved in a major terrestrial biodiversity assessment of the Comoros, including surveying Livingstone's fruit bat. Hugh Doulton is Technical Director of the Comorian NGO Dahari, for whom Is Ha Ka SAID and DANIEL SALIM work as ecological technicians. They have worked together on ecological research in the Comoros for the past 8 years and are currently implementing a major Critical Ecosystem Partnership Fund programme to identify conservation priorities on Anjouan, as well as piloting a payment for ecosystem services approach to protecting key roost sites of Livingstone's fruit bat. Mike Hudson and JefF DAWSON are conservation scientists. Richard Young was the lead scientist on the Comoros biodiversity assessment. 